\title{
Models, Metaphors and Symbols for Information and Knowledge Systems
}

\section{David Williams}

\begin{abstract}
A literature search indicates that Data, Information and Knowledge continue to be placed into a hierarchical construct where it is considered that information is more valuable than data and that information can be processed into becoming precious knowledge. Wisdom continues to be added to the model to further confuse the issue. This model constrains our ability to think more logically about how and why we develop knowledge management systems to support and enhance knowledgeintensive processes, tasks or projects. This paper seeks to summarise development of the Data-Information-Knowledge-Wisdom hierarchy, explore the extensive criticism of it and present a more logical (and accurate) construct for the elements of intellectual capital when developing and managing Knowledge Management Systems.
\end{abstract}

Keywords: DIKW, knowledge management, intellectual capital, organizational learning, systems, data, information, knowledge, wisdom, truth, records, evidence, belief.

\section{Introduction}

Whenever we build systems or develop architecture or a framework for developing systems, it is critical to have a shared understanding of the style, design elements and building blocks that we are working with. Having a simple model of the relationships between data, information and knowledge is important to be able to promote a shared understanding of how the components of a knowledge management system connect and contribute to achieving the desired business outcome. The construct of the Data-Information-Knowledge-Wisdom (DIKW) as a hierarchy is not a preferred model to underpin the design, build and operation of knowledge management systems and may lead to poor design. The presumption that if you process enough data, a system will deliver information and then knowledge is challenged by many critics of the DIKW hierarchy model. However, a closer look indicates that the DIKW pyramid is merely a simple representation by others of the propositions put forward by Zeleny, Arkov 
and Cleveland of a complex system where far more multifaceted interactions occur between the model elements.

This paper argues that it is a fallacy to believe that expensive and complex information systems will deliver valuable knowledge. Knowledge is created by people in contact with events in the physical world, including other people (and their ideas). Information and data assist the process and systems (with or without technology) and may be developed, combined or integrated to support the cognitive process.

This paper seeks to provide an alternative to the DIKW hierarchy and pyramid in the belief that it is not enough to criticise a model to make it less popular. Unless there are viable alternatives, then the first suitable model will continue to win the popularity stakes, a behaviour known as 'satisficing' (Simon, 1947). The popularity of the DIKW hierarchy is reinforced through its representation as a pyramid and an alternative graphical metaphor is proposed.

\section{Discussion on the DIKW hierarchy}

There are a number of papers summarising the DIKW hierarchy such as Sharma (2004) and Rowley (2007) with many similar references, but it is difficult to identify any single original source of the model. The literature research indicates that the model has evolved over time but we need to accelerate its evolution to provide for a rapidly changing future. This will help us to better organise and manage our intellectual assets. The article by Sharma (2004) appears to be well regarded as describing the origin of the DIKW hierarchy. However, his article is quite brief and misses some earlier references. Lambe's article on 'The unacknowledged parentage of knowledge management' (2011) is a far more comprehensive account of the history in this space and so is the paper by Rowley (2007). This paper highlights some of the significant writings to set the context.

The Data-Information-Knowledge-Wisdom (DIKW) pyramid has become popular in the information sciences as an expression of the logical relationship between these elements. The earliest found reference to the relationships between data, knowledge and wisdom is in T.S. Eliot's poem, "The Rock" (1934):

Where is the wisdom we have lost in knowledge?

Where is the knowledge we have lost in information?

Pigott, Hobbs \& Gammack (2005) identified a 1957 US Department of Defence Conference on Data Systems Languages (CODASYL) to standardise industry usage of terms involving data and its relation to information but did not appear to come to any clear consensus about its utility. 
Nicholas Henry (1974) is often cited as the originator of the DIKW hierarchy. He saw a critical need for the US Government to start managing knowledge and identified a difference between knowledge and data. He defined data as raw facts and information and knowledge as "data that changes us."

Berry and Cook (1976) stated that "knowledge, then, is defined to be the data, the relationships that exist among the data items, the semantics of the data (i.e., the use to which the information is to be put), and the rules and conditions which have been established as applying to the data of the enterprise. Knowledge involves the enterprise's awareness of the world around it and its understanding of the significance of certain pieces of information... Knowledge consists largely of the rules and special conditions which an enterprise uses to allow it to make sense out of the potentially vast sea of data which surrounds it, to limit the volume of data it collects, and to employ this data for useful purposes".

As stated earlier, Sharma (2004) provides a history of the DataInformation-Knowledge-Wisdom Hierarchy or 'Knowledge Hierarchy' as it is occasionally referred to. Sharma cited Cleveland as referring to an InformationKnowledge-Wisdom hierarchy as early as 1982 in a Futurist article.

Cleveland (1982) considered that data comes about through research, creation, gathering, and discovery while information has context. Data is turned into information by organizing it so that we can easily draw conclusions. Data is also turned into information by "presenting" it, such as making it visual or auditory. Cleveland also points to Eliot as the origin calling it "the T.S. Eliot hierarchy".

An early academic reference to the DIKW hierarchy was in 1987 and is attributed to Milan Zeleny, an American economist and Professor of Management Systems at Fordham University. Zeleny (1987 p. 60) proposed a scheme of progression from data to knowledge with each lower level subsumed by the one above it. In contrast to this he also observed that while data and information can be generated, knowledge and wisdom are human and context dependent and cannot be contemplated without involving human decision-making and judgement. Zeleny observed that "knowledge is contained in an overall organizational pattern and not in any of the components", such as an information system. He also described knowledge as a "self-producing and self-maintaining network of relations which are being continually re-created under permutations" and later described knowledge as "the process of active network configuration and reconfiguration of our human world of objects and their relations." The concept that knowledge is a process rather than a subject does not appear to be generally supported in other papers. 
Zeleny (1987) attempted to put knowledge into context by describing the analogy of the data, information, knowledge and wisdom required to bake bread. Zeleny proposed a taxonomy of knowledge with analogies and metaphors for each DIKW element that describes the progression from data to knowledge and then to wisdom.

Table 1. Zeleny's Taxonomy of Knowledge

\begin{tabular}{lllll}
\hline Element & Technology & Analogy & Management & Metaphor \\
\hline Data & Electronic Data Processing & Elements & $\begin{array}{l}\text { Muddling } \\
\text { through }\end{array}$ & Know nothing \\
\hline Information & $\begin{array}{l}\text { Management Information } \\
\text { systems }\end{array}$ & Ingredients & Efficiency & Know how \\
\hline Knowledge & $\begin{array}{l}\text { Decision support systems, } \\
\text { Expert Systems and } \\
\text { Artificial Intelligence }\end{array}$ & $\begin{array}{l}\text { Choice of } \\
\text { recipes }\end{array}$ & Effectiveness & Know what \\
& $\begin{array}{l}\text { Human systems } \\
\text { Wanagement and } \\
\text { Management Support }\end{array}$ & $\begin{array}{l}\text { Choice of } \\
\text { menu }\end{array}$ & Explicability & Know why \\
& Systems & & & \\
\hline
\end{tabular}

Source: Zeleny (1987).

Zeleny complicated the definitions by stating that "Data for some are information for others, one person's knowledge is the other's person's data". From this range of statements, which was provided with the aim of underpinning his arguments on decision-making, it is probable that there has been some misinterpretation and simplification by readers, leading to a perception that there is a linear and bounded relationship between data, information, knowledge and wisdom.

Sharma (2004) stated that in a personal communication with him in 2004 , Zeleny proposed to add "enlightenment" on top of his DIKW hierarchy. Enlightenment, according to Zeleny is "not only answering or understanding why (wisdom), but attaining the sense of truth, the sense of right and wrong, and having it socially accepted, respected and sanctioned."

Debons, Horne and Cronenweth (1988) were possibly the first to present the hierarchy in a graphical form and used the metaphor 'Knowledge Spectrum' to refer to the model.

Sharma (2004) observed that Ackoff is often cited as being the earliest to mention the DIKW hierarchy in his 1988 Presidential Address to the International Society for General Systems Research. This address was printed in a 1989 article "From Data to Wisdom". 


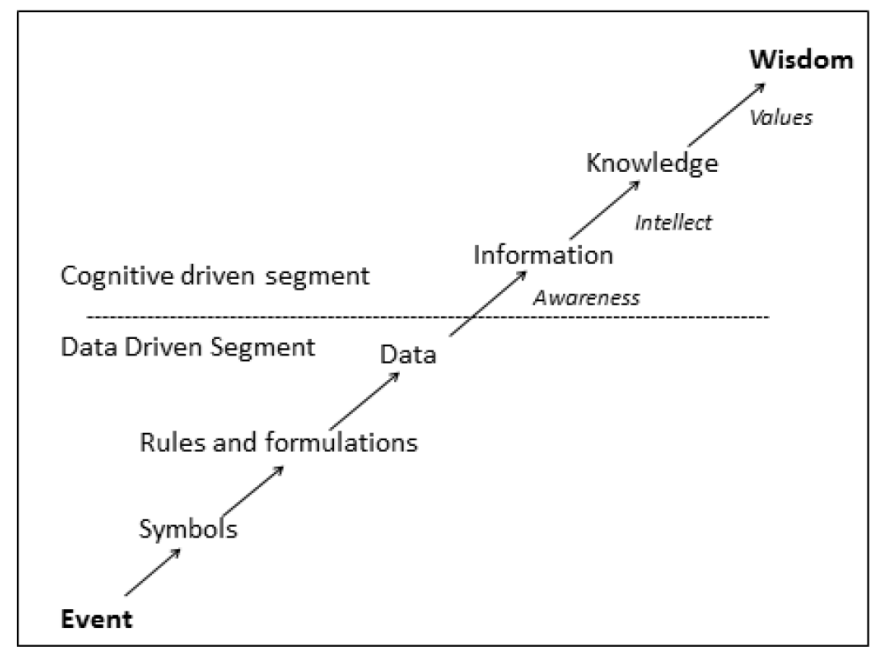

Figure 1. Knowledge Spectrum

Source: Debons, Horne and Cronenweth (1988).

Ackoff (1989) structured Data, Information and Knowledge into a hierarchical formation (but not as a pyramid) to better describe the relationship between the elements. In his address, he stated that "Wisdom is at the top of a hierarchy of types of content of the human mind. Descending from wisdom there are understanding, knowledge, information, and, at the bottom, data." Ackoff referred to the following definitions of data, information, knowledge and wisdom.

Table 2. Ackoff's definitions of data, information, knowledge and wisdom

\begin{tabular}{ll}
\hline Wisdom & $\begin{array}{l}\text { Wisdom adds value, which requires the mental function that we call } \\
\text { judgement. }\end{array}$ \\
\hline Knowledge & $\begin{array}{l}\text { Knowledge is know-how, for example, how a system works. It is what } \\
\text { makes possible the transformation of information into instructions. }\end{array}$ \\
\hline Information & $\begin{array}{l}\text { Information is contained in descriptions, answers to questions that begin } \\
\text { with such words as who, what, when and how many. Information is } \\
\text { inferred from data. }\end{array}$ \\
\hline Data & $\begin{array}{l}\text { Data are symbols that represent properties of objects, events and their } \\
\text { environment. They are the products of observation. }\end{array}$ \\
\hline
\end{tabular}

Source: Ackoff (1989).

Ackoff proposed the additional category of "Understanding" be built in to the model and structured as Data-Information-Knowledge-Understanding and Wisdom. According to Ackoff, understanding requires diagnosis and 
prescription (interaction with the physical world with skills and knowledge) and that the DIKUW elements have a temporal dimension. He stated that information ages rapidly, like news, but that knowledge has a longer lifespan. This statement is not supported with the value now seen in records and longitudinal data. Understanding "has an aura of permanence" and wisdom becomes a "permanent endowment of the race". As a result of Ackoff's work, a number of DIKUW models have sprung up as well.

Bellinger et. al. (2004) elaborated on Ackoff's model by suggesting that understanding is not a separate level, but rather that it supports the transition from each stage to the next. However this is still a linear relationship.

In addition to Sharma, Rowley (2007) has undertaken similar, but far more comprehensive research into the literature. Rowley also identified a model by Choo (2005) that defined the hierarchy as signals-data-informationknowledge. Choo contended that information flows from the external environment and is progressively assimilated and focused to enable sense making, knowledge building, and decision making.

The earliest verifiable depiction of a pyramid diagram found was by Hey (2004) as a symbol to represent the DIKW hierarchy (Figure 2). In the same year, Awad and Ghaziri also published a similar diagram. The pyramid is a powerful metaphor as it represents hierarchical strata, structure, stability, integrity, maturity, royalty, authenticity and age. The use of terms such as wisdom and knowledge in the graphic also indicate that that there is some degree of veracity to the model.

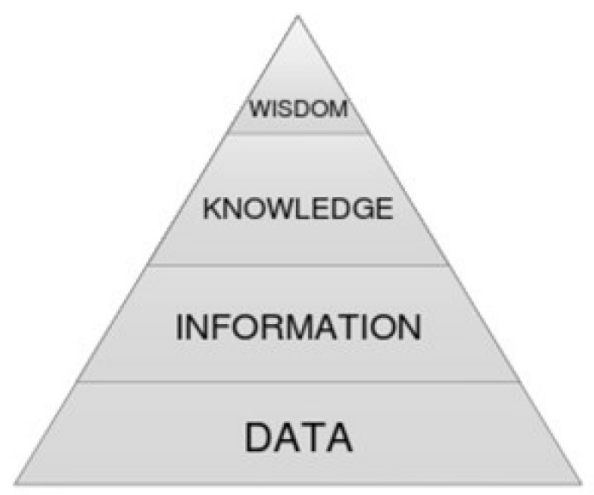

Figure 2. The knowledge pyramid

Source: Hey (2004).

Hey (2004) states that we make use of our physical experiences to help structure our thought on more complex abstract concepts. Metaphor helps us make sense of our experiences in 'knowing' by understanding it through 
concrete experiences, objects or visual aids that we can relate to. This applies to the DIKW hierarchy as all of the elements of the hierarchy are abstract concepts, particularly knowledge and wisdom. To aid in making sense of these concepts, we use symbols and develop metaphors or models to better understand them.

\section{Criticism}

McDermott (2000) cites Einstein as stating "knowledge is experience, all the rest is information". It appears there are more critics of the DIKW hierarchy than there are exponents of it. But why does the model continue to flourish? Some of the critiques are described as follows.

Popper (1963) stated that it is absurd to start with pure observations (data and information) without anything in the nature of a theory and that data is of little value unless it is based on a hypothesis (knowledge). Popper (1979) proposed a view of the universe as comprising three different worlds. The first (World 1) consists of physical bodies and events. The second (World 2) is the world of cognition, perceptions and observations. World 3 is the world of the products of the human mind, such as languages, stories, religious myths, scientific conjectures or theories, and mathematical constructions, songs, symphonies, information, documents and data. This framework stands up to scrutiny and it is used to validate our proposed model later in this paper.

Alavi and Leinder (1999) cited Churchman (1971) in stating that "To conceive of knowledge as a collection of information seems to rob the concept of all of its life.... Knowledge resides in the user and not in the collection [of information]" and claimed it is how the user reacts to a collection of information that matters.

The Israeli researcher Zins (2007) and his colleagues analysed 45 sets of definitions for data, information, and knowledge to explore the fundamental meanings of the concepts. The study classified the definitions into five classes based on whether data, information, and knowledge are each conceived of as subjective or objective. The study summarised that, in most citations, data and information are characterised as phenomena in the universal domain, and knowledge is characterised as phenomena in the subjective domain, thus existing in separate worlds. Zins states that it is a 'fairy tale' to put data, information and knowledge in a logical hierarchy.

Frické (2009) is often cited as providing a comprehensive argument against structuring Data, Information and Knowledge into a pyramid formation. He described it as a "dated and unsatisfactory philosophical position of operationalim". He contended that the model promotes the view that collected data can be promoted to information and that it implies that information can answer questions. Frické argued that "this encourages the 
mindless and meaningless collection of data in the hope that one day it will ascend to information" and then presumably on to knowledge and wisdom.

Jennex (2009) argued that the DIKW pyramid is too basic and fails to represent reality. He proposed that knowledge management with a focus on organisational learning should be included in this model.

Lambe (2012) stated that "data is the product of a knowledge-driven, purposeful piece of design work. The DIKW model implies the opposite, that knowledge is the product of a series of operations upon data."

Drucker (2011) stated that "Knowledge as normally considered by the intellectual is something very different from knowledge in the context of knowledge economy or knowledge work. For the intellectual, knowledge is what is in a book. But as long as it is in the book it is only information if not mere data. Only when a man applies the information to doing something does it become knowledge." Drucker observed that knowledge requires an external relationship to exist. Drucker is also cited (1995) as stating that "To put it in editorial terms, knowing how a typewriter works does not make you a writer. Now that knowledge is taking the place of capital as the driving force in organizations worldwide, it is all too easy to confuse data with knowledge and information technology with information."

Pigott, Hobbs \& Gammack (2005) stated that the fundamental problem with the DIKW model is that data, information and knowledge are each defined only in the context of their relationships with the other two, and it is impossible to separate the terms from one other. Unless there is a frame of reference outside of the three definitions, it is not possible to tell them apart or measure them. Comments by Zeleny support this in his description of knowledge as not being able to "refer to a 'given and fixed' set of objects 'out there', which are to be simply 'captured', represented or modelled."

Davenport and Prusak (2000) provided definitions of data, information and knowledge that are not defined in the context of their relationships with the other two terms. This supports a view that there is a distinct separation of the elements.

Rowley (2007) recognised the value of the DIKW pyramid but questioned whether these articulations present an adequate distinction between data, information, and knowledge. She stated that the problem is that there is no consensus in the description of the processes that transform elements lower in the hierarchy into those above them, leading to a lack of definitional clarity. Also, there is very limited discussion on wisdom and it appears logical that wisdom should be removed from the model altogether. Rowley (2007) also stated that "If knowledge is a property of the human mind, with the potential for action, explicit knowledge cannot be any more or less than information." 
So where does wisdom sit amongst all of this? Nürnberger and Wenzel (2011) stated that wisdom is commonly seen as a "peak of human performance that is based on excessive knowledge and judgmental capabilities". They proposed that wisdom could be considered as an extension of "intelligence" by the capability to use synthesis for problem solution. Therefore, a wise mind not only uses analysis, but also synthesis to choose behaviour appropriate to the situation to obtain a positive outcome. This is supported by the research into rapid decision-making in emergency services by Klein (1999) where he described a number of case studies where operators and leaders were able to rapidly make good decisions under considerable stress in life-threatening situations. Experience (contact with events or actions in the physical world) appears to be the contributing factor to the development of knowledge rather than an extensive amount of knowledge.

Legesse, Price and Murray (2012) claim their definition takes into account some neurological, cultural, religious, and philosophical aspects. They state that wisdom is "a demonstrated, superior ability to understand the nature and behaviour of things, people, or events ....... resulting in an increased ability to predict behaviour or events which then may be used to benefit self or others". Or, stated more simply, the ability to see patterns in complex situations and take action (before others). The definition and issue of wisdom in organisations appears to be a topic even more contentious and less mature than knowledge. Because of this immaturity and lack of common understanding of the term wisdom, it should not feature predominately in any organisational behaviour model at this time. Much of the discussion is consistent in identifying wisdom as a cognitive process or attribute, and this author would argue that it should be subsumed as an element of human capital in further discussions.

Notwithstanding the above criticisms, Zeleny, Arkov and Cleveland claimed that DIKW was a useful model, and predicated their observations with descriptions of the interactions and intellectual events that occur between the model elements and external interdependencies (events in the physical world). This is where Popper's model succeeds in bringing the physical world of events and actions into play as a potential component of an alternative model.

This paper argues that the criticism levelled at Zeleny, Arkov and Cleveland should not be that the DIKW hierarchy is wrong, but rather that the simplicity of the pyramid graphic (created by others) allows the audience to easily gloss over the external dependencies and to perceive the elements in a single plane or simple continuum, rather than the more complex and dependent arrangement that it should have represented. The DIKW hierarchy and the pyramid model place an emphasis on creating knowledge and wisdom 
from information. The focus should be on using people's knowledge, their interaction with others, events, and information to achieve the objectives of the organisation.

\section{Why is the DIKW pyramid so popular?}

There are over 70 different versions of the DIKW pyramid found on Google images (searched December 2013). There is even a DIKW Academy in the Netherlands (http://www.dikw-academy.nl/) despite the substantial criticism of the model.

We argue that the DIKW pyramid has become so popular because people crave simple models to assist in understanding complicated, complex or novel constructs. We use models to represent situations or relationships so that we can predict what may happen or to transfer understanding. Models allow us to represent the real world or our conceptualisation in a cost-effective manner to transfer knowledge to someone else or create new knowledge through simulation or stimulation (internalisation).

Moore (email 2014) contends that the DIKW pyramid resonates with people because it is a quantitative visual artefact that supports the widespread belief that the volume of data in the world is significantly greater than the volume of information, and that there is more information than knowledge and wisdom. Moore considers that this is incorrect and that the capacity of the human mind across the population of the world is still greater than the amount of stored information. Therefore, to represent DIKW as a pyramid with less knowledge than data is a fallacy. We have only been managing large volumes of information for a few decades, so it stands to reason that we are not that good at it and feel overwhelmed with the recent exponential increase and are led to believe that there is considerably more information than knowledge.

Davenport and Prusak (2000) stated that the definitions of knowledge are not neat or simple. "Knowledge is a mixture of elements and is fluid as well as formally structured. Knowledge can be intuitive and therefore, complex, unpredictable and hard to capture in words or understand completely in logical terms." Therefore, simple models such as the DIKW pyramid promise to aid in our understanding of these complex concepts.

What is a model?

Coffey and Atkinson (1996) defined a model as "an intellectual construct in artefact form that provides an abstract, highly formalised, often visual yet simplified representation of a phenomenon and its interactions."

George Box with co-author Draper (1987) is widely quoted as stating "Essentially, all models are wrong, but some are useful." This statement 
is now being challenged as a logical fallacy, particularly by the statistician community. Tarpey (2009) stated that the quote should be corrected to "All models are right... most are useless". a model is a representation of something else, usually to make the subject easier to understand. He argued that if the model was an exact replica, it would not be a model. Therefore, for a model to be right, it only has to represent the subject, to what extent is unclear and subjective. For example, we develop models to understand and predict climate change, DNA sequences and road traffic behaviour. Real world situations are subject to randomness and are complex and there is a trade-off between making a model that is cheap and easy to understand and a model that is accurate, but expensive and complicated. It is unrealistic to expect that cost effective and exact models can be developed that still convey concepts in a simpler form. Therefore, all models are subject to challenge, but effective models allow us to understand complex situations and make good (wise?) decisions within the necessary timeframe. With enough data, imperfections in any model can be detected. This is one of the reasons why sceptics are still able to challenge climate change models despite the overwhelming evidence.

So what makes a model effective or useful? Kano's model of customer satisfaction (Sauerwein et. al., 1996) can also be applied to consider the qualities of an effective model in general. The Kano model identifies three criteria for an effective model:

1) 'Must-be' requirement (is functional)

- Is self-evident or obvious

- Reflects the situation

- Is functional and meets the basic needs

- Translates concepts and arguments

- Allows us to make sense of complexity

2) 'Attractive' requirement (provides customer satisfaction)

- Is 'slick' cool or sexy

- Is clear and simple to understand

- Causes delight and 'excites' the user

- Uses metaphors, symbols or graphics

- Is quick to develop

- Is cheap and flexible

- Is transferable

- Reduces risk

3) 'Logical' requirement (is accurate)

- Is technically accurate (or close to)

- Is measureable

- Is able to incorporate data from past and current situations

- Allows outliers or spurious data/facts to be identified

- Is validated by use over time

- Supports gaming, scenarios, extrapolation, simulation and analysis 
The DIKW pyramid generally meets the first two of the three high-level criteria of being functional and attractive, but it is not logical. The challenge now is to develop a model that is more technically accurate, attractive and logical.

\section{Alternatives to DIKW pyramid}

There have been several attempts to develop alternate models, metaphors and graphics for representing the interdependencies between data, information, knowledge and wisdom. The first is the DIKUW model at figure 3 that adds the axis or element of "Understanding" into the model and incorporates a temporal concept of past and future. This model is reasonably clear but brings in a number of axes including a temporal element. It is considered to be functional, but again assumes that information comes from data and shows an axis going back in time. The model does incorporate the individual's understanding and derives context from the external environment.

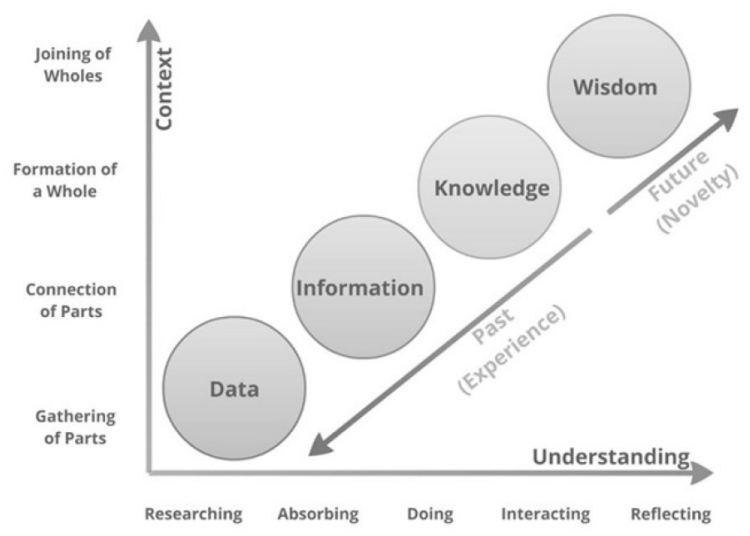

Figure 3. Model of Ackoff's DIKW hierarchy

Source: Esterbrook (2012).

The knowledge-information-data (KID) model proposed by Brodie and Brodie (2009) seeks to describe the interrelationships between the three elements when specifically related to engineering education and practice. It describes data as an underlying base supporting information with knowledge incorporated as a special form of information. Their paper admits that the distinctions between data and information are not clear cut. We argue that this is because data is a subset of information and knowledge is not.

The concept that knowledge is a subset of data is considered incorrect and is supported by most of the references cited in this paper. Where Brodie 
and Brodie add value is in their recognition of the value and purpose of simple models in communicating concepts as shown in figure 4.

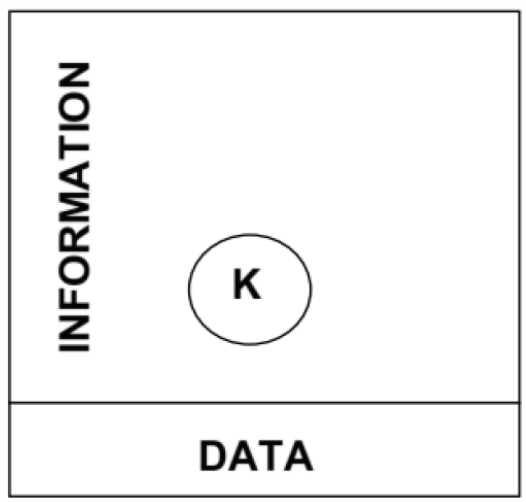

Figure 4. KID model

Source: Brodie and Brodie (2009).

The Infoengineering model at figure 5 describes information and knowledge as separate elements but also describes data as being quite separate from information. The assertion that "data is facts" is challenged as there is a copious amount of data that is incorrect.

This model appears to be clear, simple and functional. However, it assumes that information comes from data and excludes the impact of the physical world or events on the development of knowledge and decisions. The use of metaphor in the symbols to represent data, knowledge, information and decisions makes it quite attractive.

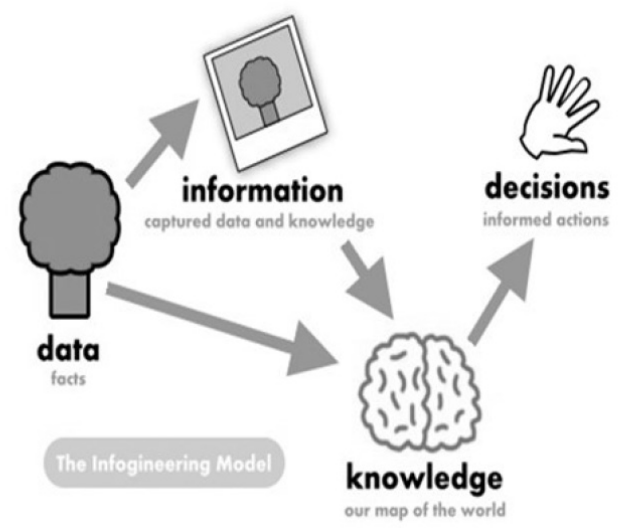

Figure 5. Infoengineering model Source: Ingebrigtsen (2007). 
Faucher, Everette and Lawson (2008) offered a new model (no graphic available) that they termed as Existence to Enlightenment (E2E) describing it as a "cognitive system of knowledge" that redefines the scope of knowledge management. They criticised the DIKW model and claimed that the boundaries are too difficult to define. They proposed a continuum with Existence at the lower end and Enlightenment at the higher end. While this is a move away from a hierarchical relationship among data, information, knowledge, and wisdom, this model still places DIKW on a single plane with no clear delineation. While simple, no graphic or symbol could be found to articulate their model, therefore rating lower on the Kano criteria of attractiveness as well as lower on accuracy.

The Noetic Prism (from the term 'res noetica', which literally means 'mental stuff') developed by Pigott, Hobbs and Gammack (2005) steps away from a continuum model and looks at Data, Information and Knowledge in three different planes. The Noetic Prism has three vertices of granularity, shape and scope with a vertical axis representing complexity. They claimed that only a small shift in perspective is required to translate existing terms to the context of the noetic prism (figure 6). They proposed that the granularity plane be used for Information, the shape plane for Data and the scope plane for Knowledge. This is an ambitious and logical attempt to break the concepts associated with the DIKW pyramid, but it is not clear how it can gain broad acceptance. In Kano terms it may be logical, clear and simple (attractive), but it is not that functional as there is too great a leap of understanding required to embrace and then use the model. The use of a prism as a metaphor probably creates more ambiguity than clarity.

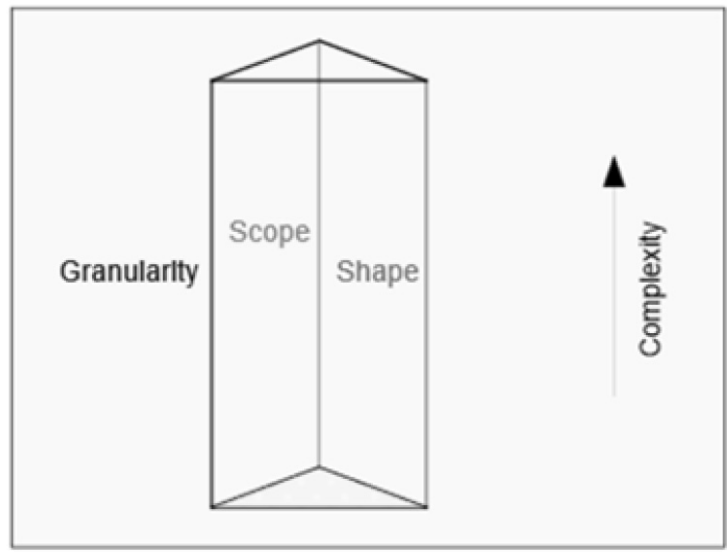

Figure 6. Noetic Prism

Source: Pigott, Hobbs \& Gammack (2005). 
The "Data to Wisdom" Curve (Pór 1997) shown at figure 7 depicts the hierarchy as a learning journey whereby we progressively transform the raw, unfiltered facts and symbols into information, knowledge, and eventually into intelligence and wisdom. It indicates a maturity or evolution from data and information to knowledge and wisdom over time and has less of a relationship between the elements. The Curve appears to be more an indication of where we are as a society. However, the explosion of data and information indicate that this curve might go the opposite direction. It is difficult to tell as there are too many variables on the chart and the model appears lower on the scale for logic, function and attractiveness, with no effective use of metaphor or symbol.

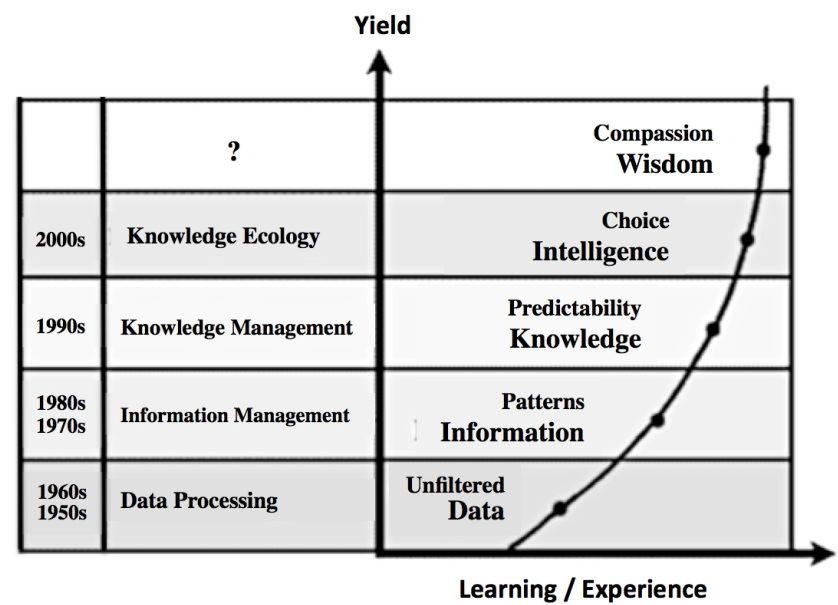

Figure 7. The data to wisdom curve Source: Pór (1997).

Firestone (2001) proposed replacing the pyramid with a cyclical model (figure 8). In his Knowledge Life Cycle (KLC) model, information is not constructed from data as data is a subset of information. Firestone claimed that data and knowledge are made from pre-existing information, that is, "just information". Data, knowledge, and problems are used in the knowledge life cycle to produce more information and new knowledge. While attractive and somewhat functional, this model does not explicitly indicate the input of the external environment (apart from problems). The utility of the model becomes clearer when the knowledge life cycle is considered in the context of the 3 Worlds defined by Popper (1979). However, the depiction of "information" and "just information" creates some initial confusion when the graphic is considered in isolation. 


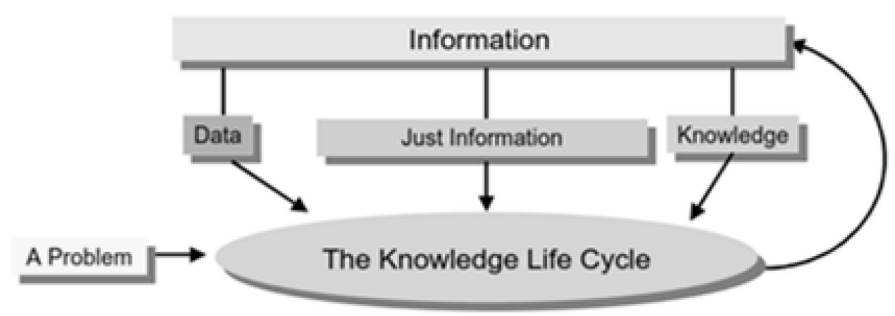

Figure 8. The Knowledge Life Cycle model

Source: (Firestone 2001).

\section{Towards an alternative model}

Popper's 3 Worlds concept (1979) provides an alternate and useful view on data, information and knowledge. Popper's 1979 lecture on human values proposed a pluralist view of the universe that recognised at least three different but interacting sub-universes. The First World deals with the physical world of objects, people and events. The Second World is the mental, cognitive or psychological world. Popper described the Third World as containing products representative of the human mind. This Third World includes stories, scientific theories, mathematical constructions, songs, paintings and sculptures. According to Popper's model, information is a representation of cognitive activity (knowledge) and is therefore a World 3 artefact.

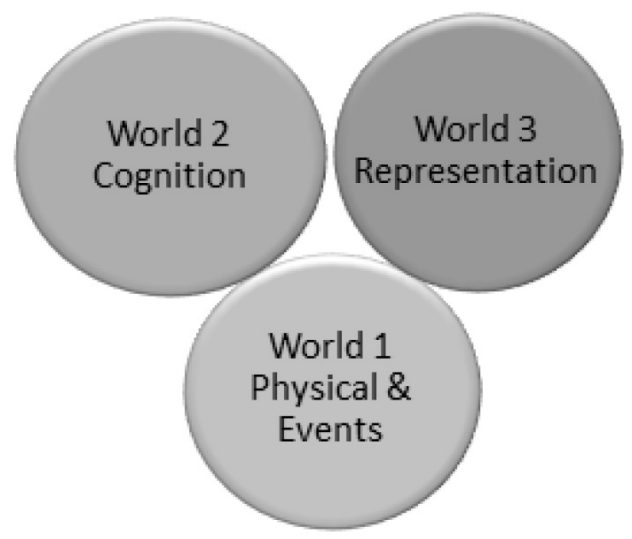

Figure 9. Popper's 3 Worlds

Popper contended that many of the objects belonging to World 3 belong at the same time also to the physical World 1 . World 3 contains data and recordings, therefore representing events and objects in World One as well 
as the cognition of World 2. Popper gives the example of Michelangelo's sculpture, The Dying Slave, as an object belonging to World 1 of and as an expression of Michelangelo's creative mind, therefore also belonging to World 3. While Popper has been instrumental in providing a different lens through which to view information and knowledge, we need a model that allows modern artefacts to better fit into a contemporary framework. This applies to electronic documents, optical media, video, software, artificial intelligence as well as art and music. Popper did not consider where software exists but we would suggest that it sits in World 3 and can act on the physical world without cognitive interaction from World 2. Artificial Intelligence is even more difficult to classify. As a result of the age of this model, a more contemporary alternative is now required.

Wiig (1997) argued that there is a considerable overlap of Intellectual Capital Management (ICM) with Knowledge Management (KM). ICM is relatively strategic and deals with intellectual assets such as intellectual property, structural capital (data, information and documents), organisational capital and other intangible assets. He stated that KM has a more tactical and operational focus. Therefore, Data, Information, Knowledge and Wisdom can be considered within the context of organisations and as a subset of intellectual capital.

Wiig's breakdown of intellectual capital into a series of overlapping facets is relatively complex. Seemann et. al. $(2000$, p3) suggested that intellectual capital can be expressed as three simpler classes:

1) Human Capital: An individual's capabilities

2) Social Capital: a capacity to collaborate

3) Structural Capital: The organization's processes, systems, \& procedures

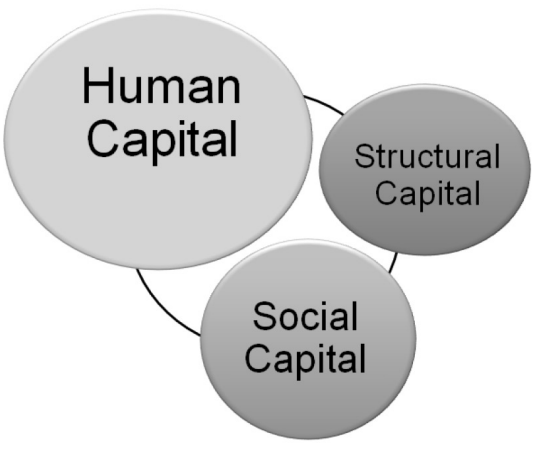

Figure 10. Key components of intellectual capital 
We see that there is a reasonable alignment between these three classes of intellectual capital and Popper's 3 Worlds, reinforcing the insight that knowledge and information are worlds apart:

1) Social or Relational Capital - World 1 Objects and Events

2) Human Capital - World 2 Cognition

3) Structural (Organisational) Capital - World 3 Representations

Seemann et. al. (2000) argued that most definitions of intellectual capital fail to account for social capital, although Wiig (1997) clearly described something similar as customer capital. Seemann et. al. also stated that social capital is reflected in the ability of groups to form effective networks and collaborate. This collaboration occurs as events consisting of individuals interconnecting and it occurs in the Popper's World 1. Seemann et. al. described human capital as the "knowledge, skills, and experiences possessed by individual employees" and this aligns well with Popper's description of World 2.

Seemann et. al. also described structural capital as "basically everything that remains in a firm after its employees go home." It includes the explicit, rule-based knowledge embedded in the organization's work processes and systems, or encoded in written policies and training. This is generally aligned with Popper's World 3. Wiig (1997) classified this as organisational capital.

If we accept the argument that the three intellectual asset classes sit predominantly in three different worlds, it would be illogical to state that they can sit in a single plane or a hierarchy of relative value. It is apparent that each class is valuable in its own right and each may have different management strategies applied to it, to be able to increase the value gained from each asset class by an organisation. It would follow that human and social capital should be managed using knowledge management tools and techniques. Structural capital should be managed using information management tools and techniques.

From this perspective, there is then a clearer difference between information and knowledge and a more logical progression to better define, develop and operate a knowledge management system as distinct from an information management system.

\section{Clarifying the terms}

Jennex (2009) made a salient point that it is not productive for researchers or academics to overly focus on defining some of these terms as it distracts from the discussion on the subject. The Knowledge Bucket (Banks 2014) has a collection of over 60 definitions of knowledge management, all of which may be considered relevant and correct within their own contexts (also indicating the immaturity of the field). 
As Liew (2007) observed, the difficulty is that many definitions define intellectual elements in terms of each other. For example, data is defined in terms of information, information is defined in terms of data and/or knowledge, and knowledge is defined in terms of information. The definitions become circular and obtuse. So while the definitions provided by many scholars and experts in the field are acknowledged as correct (because all models are correct), it is of greater value to adapt some definitions that place Data, Information, and Knowledge into a more logical (in the Kano sense) organisational construct.

Davenport and Prusak (2000) defined data as "discrete, objective facts about events". However, data may not always be factual, so we will adopt the definition by McDonald (oral information, 28 March 2014) defining data as the values of an attribute of an object (subject or event). Data is a subset of information, because it is usually a record of an action or of the cognition of a person in a structured format.

Information is considered to be "the representation of an action or a cognitive concept". Facts, records and evidence are also representations of cognition, an object or an action in the physical world and are therefore classed as information.

Knowledge in this context is "a fluid mix of framed experience, values, contextual information, and expert insights that provides a framework for evaluating and incorporating new experiences and information" (Davenport and Prusak, 2000)

As previously argued, wisdom is considered to be a subset of cognition (knowledge) and is less relevant to a management model. We only reference the term here because it exists in the current models.

\section{Defining a better model}

If we were to construct a model that better represented the relationships between Data, Information, Knowledge (and Wisdom), it would need to meet most of the following business rules or attributes (in addition to those of Kano's model):

- The relationships would be multi-directional as data informs the creation of knowledge, and knowledge is represented as information

- All elements would interact with actions or events in the physical world

- The elements would not sit on a continuum as they exist in different worlds

- Facts, data, records, evidence are a subset of information (structural capital) 
- Truth and belief would appear as a subset of knowledge (human capital)

- Wisdom is shown to be less relevant and is a subset of knowledge

- Social capital is shown to be created during events or actions

- It should be capable of being easily drawn or replicated to compete against the DIKW pyramid graphic.

Therefore, the simplest relationship between data, information, knowledge and wisdom could look like a basic diagram as shown at figure 11. Symbols are used as metaphors to assist the audience in making sense of the concepts by understanding them through less abstract images that they can relate to. The challenge is not to make it too simple or allow space for misinterpretation. Data and wisdom are now shunted out of the picture.

In the model below, the term "Action" is used to represent the physical or social element because it is a less passive term than "Event" or a descriptor of a physical world. We want knowledge and information to result in actions and results for our organisation. This Action-Knowledge-Information (AKI) model represents the concept that knowledge is created from framed experience, values, contextual information and expert insights. Information is created as a representation of an action, object or a cognitive concept (knowledge). The model relates effectively to intellectual capital models by both Wiig (1997) and Seemann et. al. (2000) as well as the 3 Worlds models of both Popper and Firestone.

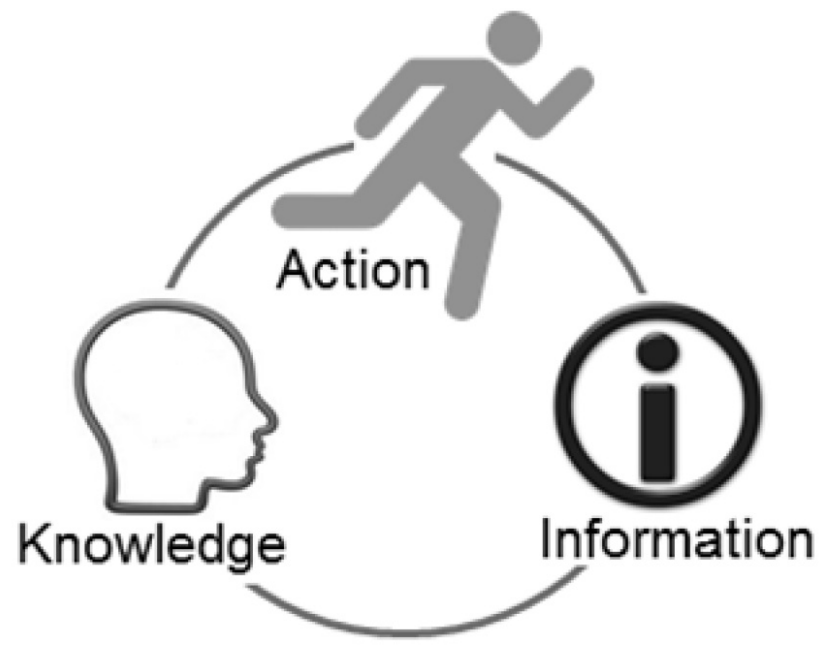

Figure 11. AKI: a preferred model of information and knowledge 
Table 3 shows some of the elements that sit within the AKI Model. This allows the model to be unpacked and applied in a practical sense.

Table 3. Elements of the AKI Model

\begin{tabular}{lll}
\hline Action & Knowledge & Information \\
\hline Social Capital & Human Capital & Structural Capital Facts \\
Places & Wisdom & Fiction \\
Events & Beliefs and values & Data \\
Objects & Emotions & Records \\
Gravity & Understanding & Evidence \\
Experience & Concepts and ideas & Artificial Intelligence \\
Relationships & Perceptions and insight & Designs \\
Innovation & Intent & Laws \\
Life and death & Skills & Procedures \\
Performance & Truth & Software \\
Time and Space & Culture & Art and music \\
Politics & Religion & \\
\hline
\end{tabular}

If we assess the AKI Model against the criteria for Kano's model we can see that the diagram is clear and simple to understand. It shows a relationship between actions, information and knowledge and that the three elements are connected but discrete. Table 3 shows where data and wisdom fit in to avoid the criticism of the model being incomplete. Their inclusion also opens the door for further work on the topic of wisdom in organisations into the future. The model translates concepts and arguments far more easily than a direct use of Popper's 3 Worlds.

The AKI model is quick to develop, is cheap, flexible and transferable. It is technically accurate (or close to) and allows outliers or spurious data/ facts/object to be identified. It uses simple symbols to allow the audience to relate better to the abstract concepts it represents (but may possibly be oversimplified). The question is, does it meet the subjective criteria of causing delight and exciting the user? The challenge now is to test this model in the market and see if our design is viable.

\section{Why this matters - implications for designing and developing systems} Confusion and debate surrounding the DIKW continuum has resulted in a lack of consistency in how KM systems should be developed and implemented. Davenport and Prusak (2000) stated that "confusion about what data, information and knowledge are - how they differ, what the words mean - has resulted in enormous expenditures on technology initiatives that rarely deliver what the firms spending the money needed or thought they were getting".

Wenger (1998) stated that traditional knowledge management approaches and systems attempt to capture existing knowledge within formal 
systems, such as databases. This "externalisation" activity places a focus on managing the information rather than the knowledge. To systematically address the kind of dynamic "knowing" that makes a difference in practice requires the participation of people who are fully engaged in the process of creating, refining, communicating, and using knowledge.

The question now is to determine how the above model described at 11 would impact on designing and developing KM systems and what is the difference between an information management System and a KM System.

As well as differentiating knowledge from information and data (different classes of intellectual capital), we can use the AKI model to indicate the differences between management systems. This would enable us to better define an appropriate purpose for the system and utilise a suitable architecture. Without these, the likelihood of realising the expected benefits of the system from the resources invested is reduced.

The AKI model allows us to think of a KM system as a new species of communication and management system that is enabled by technology, is cognizant of information, and takes into account the complex nature of intangible assets, to support the flow of knowledge in organisations.

A system cannot function in one world alone and requires aspects from the other two worlds to operate effectively. We develop and employ information management systems and strategies to manage representations of cognition and events and objects. Therefore, an information management system aims to manage the structural capital of an organisation. This includes information, data, records and evidence. Electronic Document and Records Management, Content Management, Digital Resource Management and Intranets are examples of information management systems and they are good at supporting the management of the 'know when' and the 'know where'.

We define a KM system as a technology-based or non-technical interconnected group of functions that enables or facilitates either (or a combination of) the discovery, capture, integration, sharing or delivery of the knowledge required by an organisation to meet its objectives. It can comprise a part of a knowledge management initiative or strategy to improve the utility of an organisation's intellectual capital (McDonald and Williams, 2011). a KM system is more concerned about the 'know why', know who', 'know how' and 'know what'.

Most KM systems are dependent on information. Similarly, other systems are useless unless there is some 'know why' and 'know how' about the system and its subject. In his address to the National Press Club (8 May 2014) Dr Barry Kirby told the story of how a clean drinking water supply was installed in a remote village in Papua New Guinea by an overseas non-governmental 
organisation to assist the village and reduce sickness. The water supply was turned off because no one taught the villagers how to use a tap and they would leave it running all day (Kirby, 2014). Information systems are similar. Users need to be given the knowledge of 'why' the system was set up, 'what' it is for and 'how' to use the 'tap'.

Because knowledge systems are different to information systems, it is logical that we should apply different systems, architectures and strategies. We develop and employ KM systems to increase the value we obtain from the human and social capital of our people rather than the value from our information (structural capital). Note that information (structural capital) assets are owned by the organisation but knowledge (human and social capital) assets are owned by people and are only potentially available for use by their host organisations, depending on how well people are managed.

Frank (2001, p2) states that a KM system should:

- have an emphasis on concepts and reason

- re-use existing knowledge

- integrate with information

- support awareness

While a valuable starting point, these appear to be principles rather than requirements of a KM system. a KM system should be deliberately developed and managed to support and enhance knowledge-intensive processes, tasks or projects. Such systems would include interaction with information, action and events, including interaction with other people.

Because recent advances in technology have enabled us to dramatically improve our ability to engage others across both time and space, we are continually tempted to think of a KM system as an information technology (IT) system. Zaharova and Galandere-Zile (2002) argued that "technology by itself does not constitute a knowledge management program. Technology is an enabler that can facilitate the management of an organisation's intellectual and knowledge-based assets, especially in large, geographically dispersed organisations."

In a KM system, the subject being managed is the social and intellectual capital of people associated with the organisation. KM systems should include tools, techniques and strategies tailored to specific business requirements. These may include techniques such as sense making, use of narrative, mentoring, communities of practice, knowledge cafes and after action reviews. Nearly 50 knowledge management techniques are identified in the Knowledge Bucket curated by Banks (2014). Tiwana (2001) stated that "it is vital to recognise that technology's most valuable role in knowledge management is broadening the reach and enhancing the speed of knowledge transfer". 
An example of a KM system is the process that nursing staff employ for transferring knowledge about patients and the operation of the ward at the end of a shift. They rely on documentation and patient notes, which are often supported by information technology systems. However, the main knowledge transfer exists in the interaction between trained professionals with a common understanding and common objectives. The same may be seen where the knowledge of a community is handed down through story rather than through a platform such as Facebook. Similarly, an after action review system is capable of exposing and creating new knowledge for the benefit of the participants and the organisation. Technology should only be seen as a component of a KM system and of information management. By clarifying the differences between information and knowledge, the AKI model should assist business analysts and organisational developers to undertake system development using appropriate architecture.

\section{Conclusion}

Despite considerable criticism, the DIKW hierarchy continues to be popular within the general information management and technology community, primarily because few effective alternatives have been proposed. While early exponents of the hierarchical framework enhance their definitions with discussion about the dependencies between the elements and the outside world, a simplistic interpretation continues to pervade. Much of the criticism states that the hierarchy has oversimplified the complex nature of knowledge and that the elements should not be defined in terms of each element. Where many critiques of the hierarchy fall short is in still considering that the elements exist in a continuum and few propose an effective alternative to challenge the DIKW pyramid graphic. a simple (AKI) diagram with unambiguous symbols shows a more egalitarian relationship between the elements that is more accurate and is a viable competitor to the DIKW pyramid. This paper is the initial step in testing that hypothesis.

The debate, confusion and misunderstanding of the differences between data, information and knowledge means that we often attempt to manage knowledge with information management techniques and systems, and then are disappointed when the outcomes are not achieved. This paper uses the development of the AKI model to argue that:

1) knowledge is a different class of intellectual capital than information and data;

2) accurate models, metaphors and symbols allow us to more easily make sense of concepts;

3) a KM system is a new species of communication and management system specific to human and social capital; and 
4) design and development of a KM system requires different architectures and strategies.

\section{Acknowledgments}

I acknowledge members of the actKM community who supplied references and engaged in a robust discussion on this topic, although not always in agreement with the author. These include: Bill Hall, Matt Moore, Vince Hughes, Fred Nickols, Stephen Moore, Patrick Lambe, Laurence Lock Lee, Ian Fry, Jim Brander, Nerida Hart, Han Van Loon (2014) and Diarmuid Pigott.

\section{References}

Ackoff, R.L. (1989). From Data to Wisdom. Journal of Applied Systems Analysis, 16, 3-9.

Alavi, M., and Leidner, D. E. (1999). Knowledge management systems: issues, challenges, and benefits. Communications of the AIS, 1(2es), 1.

Banks, C. (2014). The Knowledge Bucket (Wiki) Retrieved from http:// knowledgebucket.wikispaces.com/.

Bellinger, G., Castro, D., Mills, A. (2004). Data, Information, Knowledge, \& Wisdom. Retrieved from http://www.systems-thinking.org/dikw/dikw.htm.

Berry, J.F. and Cook, C.M. (1976). Managing Knowledge as a Corporate Resource. Department of Defence: Washington, DC.

Box, G.E.P., and Draper, N.R., (1987). Empirical Model Building and Response Surfaces. John Wiley \& Sons: New York, NY.

Brodie, I., and Brodie, L. (2009). a knowledge-information-data concept model for engineering education. Australasian Journal of Engineering Education, 15(3), 137-144.

Choo, C.W. (2005). The knowing organization: how organizations use information to construct meaning, create knowledge and make decisions, Published to Oxford Scholarship Online: September 2007.

Churchman, C.W. (1971). The Design of Inquiring Systems: Basic Concepts of Systems and Organisations. Benis Books: New York.

Cleveland H. (1982). Information as Resource. The Futurist, December, 34-39. Coffey, A., and Atkinson, P. (1996). Making sense of qualitative data: Complementary research strategies. Sage.

Davenport, T.H. and Prusak, L. (2000). Working Knowledge: How Organizations Manage What They Know. Harvard Business School Press, Boston: MA, USA.

Debons, A., Horne, E., Cronenweth, S. (1988). Information Science: An Integrated View. Boston: G.K. Hall.

DIKW Academy. (2013). Retrieved from http://www.dikw-academy.nl/.

Drucker P. (1995). The Post-Capitalist Executive. Managing in a Time of Great Change. Penguin: NY. 
Drucker, P. (2011). The age of discontinuity: Guidelines to our changing society. Transaction Publishers.

Eliot, T.S. (1934). The Rock, Faber \& Faber.

Esterbrook, S. (2012). What is Climate Informatics? Retrieved form: http:// www.easterbrook.ca/steve/2012/09/what-is-climate-informatics/.

Faucher, J.B., Everette, A.M., \& Lawson, R. (2008). Reconstituting knowledge management. Journal of Knowledge Management, 12(3), 3-16.

Firestone, J.M. (2001). Key Issues In Knowledge Management. Journal Of The $\mathrm{KMCl}, 1(3)$.

Frank, Ulrich. (2001). Knowledge Management Systems: Essential Requirements and Generic Design Patterns. Institute for Information Systems Research, University of Koblenz. Retrieved from http://www.unikoblenz.de/ iwi/ publicfiles/PublikationenFrank/ISE2001.pdf (Reprinted from Proceedings of the International Symposium on Information Systems and Engineering, ISE'2001. Las Vegas: CSREA Press, 2001, pp. 114-121).

Frické, M. (2009). The knowledge pyramid: a critique of the DIKW hierarchy. Journal of Information Science, 96-131, Retrieved from http://arizona. openrepository.com/arizona/bitstream/10150/105670/1/The_ Knowledge_Pyramid_DList.pdf.

Henry, N. (1974). Knowledge management: a new concern for public administration. Public Administration Review, 34(3), 189-196.

Hey, J. (2004). The data, information, knowledge, wisdom chain: the metaphorical link. Intergovernmental Oceanographic Commission.

Ingebrigtsen, N. (2007).The Differences Between Data, Information and Knowledge. Retrieved from http://www.infogineering.net/datainformation-knowledge.htm.

Jennex, M.E. (2009). Re-visiting the knowledge pyramid. System Sciences. HICSS'09. 42nd Hawaii International Conference. IEEE.

Kirby, B. (2014). National Press Club: Dr Barry Kirby, National Press Club, Canberra. Retrieved from http://www.abc.net.au/news/2014-05-07/ national-press-club-dr-barry-kirby/ 5436988 .

Klein, G. (1999). Sources of Power: How People Make Decisions. Cambridge, MA: MIT Press.

Lambe, P. (2011). The unacknowledged parentage of knowledge management. Journal of Knowledge Management, 15(2), 175-197.

Lambe, P. (2012). in the Knowledge Management for Development (KM4Dev). Retrieved from http://wiki.km4dev.org/DIKW_model.

Legesse, B, Price B.H., and Murray E.D. (2012). Brain-Behavior Relations. In: Encyclopedia of Human Behavior, 2nd Edition. Edited by: Ramachandran, V. S. Academic Press.

Liew, A. (2007). Understanding data, information, knowledge and their interrelationships. Journal of Knowledge Management Practice, 8(2).

McDermott, R. (2000). Why information technology inspired but cannot deliver knowledge management. Knowledge and communities, 41(4), 21-35. 
McDonald, C. (2014). Interview with Prof. Craig McDonald at University of Canberra, 12 March 2014 by D.J. Williams.

McDonald, C. and Williams, D. (2011). Developing a KMS, University of Canberra. Retrieved from http://www.slidefinder.net/d/designing_a_ kms_v2/32955764.

Moore, M. (2014). email from Matt Moore to david.j.williams@canberra. edu.au dated 6 May 2014.

Nürnberger, A., and Wenzel, C. (2011). Wisdom-the blurry top of human cognition in the DIKW-model? Proceedings of the EUSFLAT conference, Aix-Les-Bains, France (Vol. 1, pp. 584-591).

Pigott, D., Hobbs, V.J., and Gammack, J. (2005). The noetic prism. Computing and Information Systems, 9(2), 78-88.

Popper, K. (1963). Conjectures and Refutations. The Growth of Scientific Knowledge. London and New York.

Popper, K. (1979). Three worlds. The Tanner Lecture on Human Values, Ann Arbor: University of Michigan.

Pór, G. (1997) Designing knowledge ecosystems for Communities of Practice. Retrieved from http://www.co-i-I.com/coil/knowledge-garden/dkescop/ dwcurve.shtml.

Rowley, J. (2007). The wisdom hierarchy: representations of the DIKW hierarchy. Journal of Information Science, 33(2), 163-180.

Sauerwein, E., Bailom, F., Matzler, K., and Hinterhuber, H.H. (1996, February). The Kano model: How to delight your customers. International Working Seminar on Production Economics (Vol. 1, pp. 313-327).

Seemann, P., DeLong, D., Stukey, S., and Guthrie, E. (2000). Building intangible assets:astrategicframeworkforinvesting in intellectualcapital. Knowledge management: Classic and contemporary works. Retrieved from http:// www.smartworkforcestrategies.com/Portals/0/Published\%20Articles/ DeLong-BuildingIntangibleAssets-FrameworkForIntellCapital-BookChp. pdf.

Sharma, N. (2004). The Origin of the Data Information Knowledge Wisdom Hierarchy Retrieved from https://docs.google.com/file/ d/0BzMm6cRs9IE6YW5Scm5WWGR6RDQ/edit.

Simon, Herbert A. (1947). Administrative Behavior: a Study of DecisionMaking Processes in Administrative Organization. New York: Macmillan.

Tarpey, T. (2009). All Models are Right...Most are Useless. Retrieved from http://andrewgelman.com/wp-content/uploads/2012/03/tarpey.pdf.

Tiwana, A. (2001). The Essential Guide to Knowledge Management E-Business and CRM Applications. Prentice-Hall, Upper Saddle River: NJ, USA.

Van Loon, H. (2014, 30 April). From data to wisdom, actKM discussion list. Retrieved from http://actkm.org/mailman/listinfo/actkm_actkm.org by subscribing to the list and accessing the archives.

Wenger, E. (1998). Communities of practice: Learning as a social system. Systems Thinker, 9(5), 2-3. 
Wiig, K.M. (1997). Integrating intellectual capital and knowledge management. Long Range Planning, 30(3), 399-405.

Zaharova, S., and Galandere-Zile, I. (2002). The impact of the knowledge management to business processes. In International Conference: Traditional and Innovative in the Lasting Development of Society, Rezekne, Latvia, 298-304. Rezekne: Rezekne Higher Education Institution.

Zeleny, Milan (1987). Management support systems: Towards integrated knowledge management. Human Systems Management, 7(1), 59-70.

Zins, C. (2007). Conceptual approaches for defining data, information, and knowledge. Journal of the American Society for Information Science and Technology, 58(4), 479-493.

\section{Abstrakt (in Polish)}

Przeglqad literatury wskazuje na to, że Dane, Informacje i Wiedza sq wciq̨ż umieszczane w hierarchicznej konstrukcji, gdzie informacje sq bardziej cenione niż dane i mogq być przetworzone w cennq wiedzę. Mqqdrość w dalszym ciqgu jest dodawana do tego modelu, co zaciemnia cała kwestię. Model ten ogranicza naszq zdolność do logicznego myślenia o tym jak i dlaczego tworzymy systemy zarzqdzania wiedzq do wspierania i udoskonalania procesów, zadań czy projektów wymagających znacznej wiedzy. Artykuł ten próbuje podsumować rozwój hierarchii Dane-Informacje-Wiedza-Mqdrość, przedstawia jego krytykę i proponuje bardziej logicznq (i dokładnq) konstrukcję obejmujqca składniki kapitału intelektualnego, która może być zastosowana przy tworzeniu i zarzq̨dzaniu Systemami Zarzqdzania Wiedzq

Słowa kluczowe: DIKW (Dane-Informacje-Wiedza-Mq̨rość), zarzqqdzanie wiedzq, kapitał intelektualny, organizacyjne uczenie, systemy, dane, informacje, wiedza, madrość, prawda, dane archiwalne, dowody, przekonanie.

\section{Biography}

David Williams's early background is in project management in the Australian construction industry on large projects such as Loy Yang power station in Victoria, the Australian Submarine Construction Facility in South Australia, Bruce Stadium and New Parliament House in the ACT. He joined the Department of Defence in 1989 on the New Submarine Project before working across Defence in the management fields of human resources, information, knowledge, quality, risk and enterprise architecture. David has also worked as a management consultant in facilities management and enterprise architecture. He was previously the information architect for the Department of Employment and Workplace Relations. David has managed and implemented several major procurement projects in government departments for both services and solutions including projects for the Energy Security Programme. David has introduced a Project Management Office into the Department of Human Services and is now delivering services back into 
government departments on a consulting basis in decision support systems and procurement management practices. David has a Diploma in Engineering, a Graduate Diploma in Public Sector Management and a Master's degree in Project Management. He is the President of the actKM forum Community of Practice and is on the Board of the Institute for Information Management.

TYM: Faculty of Business, Government \& Law, University of Canberra, Room:11, Bldg C44, Locked Bag 1, University of Canberra, ACT 2601, AUSTRALIA. Tel (61) 412237695 Email David.j.williams@canberra.edu.au, vertigo@netspeed.com.au. Skype: david_williams546. Linkedln: http://www. linkedin.com/pub/david-williams/0/346/36b. 
